\title{
The production of Pleurotus sajor-caju in peach palm leaves (Bactris gasipaes) and evaluation of its use to enrich wheat flour
}

\author{
Paula Fernanda Bomfim Oliveira COGORNI ${ }^{1}$, João Guilherme SCHULZ², Endi Pricila ALVES ${ }^{2}$, \\ Regina Maria Miranda GERN ${ }^{2}$ Sandra Aparecida FURLAN ${ }^{1,2}$, Elisabeth WISBECK ${ }^{1,2 *}$
}

\begin{abstract}
The aim of this study was to evaluate of Pleurotus sajor-caju production in peach palm leaves and the addition of different fractions of mushroom powder to wheat flour to increase its nutritional value without changing its characteristics. The best yield (48.4\%), biologic efficiency (4.5\%), and $\operatorname{Pr}(0.36 \mathrm{~g} /$ day) values were obtained using $20 \%$ inoculum fraction and $10 \%$ rice bran fraction. The Pleurotus sajor-caju fruiting body cultivated under these conditions had the following composition in $100 \mathrm{~g}$ : $29.91 \mathrm{~g}$ (carbohydrates), $42.92 \mathrm{~g}$ (proteins), $1.24 \mathrm{~g}$ (lipids), $15.93 \mathrm{~g}$ (fibers), $7.42 \mathrm{~g}$ (ashes), $1.6 \mathrm{~g}$ (phosphorus), $2.7 \mathrm{~g}$ (potassium), $8.73 \mathrm{mg}$ (iron), $23.75 \mathrm{mg}$ (sodium), $0.34 \mathrm{mg}$ (thiamine), and $0.57 \mathrm{mg}$ (riboflavin). The wheat flour with mushroom powder had reduced sugar content, but it did not have increased fat content. The fiber, protein, phosphorus, potassium, iron, and riboflavin contents were increased mainly when $10 \%$ mushroom powder was added to the wheat flour. Furthermore, this flour does not undergo drastic alterations in its physicochemical characteristics such as in moisture, wet gluten, color, and falling number.
\end{abstract}

Keywords: nutritional value; wheat flour; mushrooms.

\section{Introduction}

The cultivation and extraction of hearts of palm produce large amounts of waste, and according to Soto et al. (2005), only a small part of it is commercialized in the form of canned hearts of palm (estimated to be less than $10 \%$ of the palms); thus, most of the palm trees remain in the soil after extraction.

The incorporation of non-decomposed organic matter in the soil implicates in the humification process, prompting intense microbial activity leading to a temporary nitrogen deficiency, which is consumed by the microorganisms to the detriment of the plants (Medina, 1990). Furthermore, the cultivation of peach palms for the production of hearts of palm is intensive (5000 to $6600 \mathrm{plants} / \mathrm{ha}$ ), and the crops occupy the most diverse agro-bioclimatic regions (Bovi, 2000).

One feasible way of minimizing this probable environmental impact is by making better use of the cultivation using alternative approaches that could increase revenue for the producer while using the same space. This agroecological waste consists of lignocellulosic plant matter, which could be used as a renewable source of substrate for biological conversion into microbial biomass of high nutritional value (Philippoussis, 2009).

The Pleurotus genus of the class Basidiomycetes belongs to a group known as "white rot fungi" since they produce a white mycelium and degrade lignin and cellulose (Carvalho et al., 2010). Its cellulolytic enzyme complex contains enzymes such as cellulase, ligninase, cellobiase, laccase and hemicellulase (Kong, 2004). However, as far as its cultivation is concerned, it is known that nutrient restriction limits mushroom growth (Carvalho et al., 2010) and that the inoculum fraction has a significant influence on the productive parameters yield and biological efficiency (Bhatti et al., 2007).
The fruiting bodies (mushrooms) of the Pleurotus genus are appreciated not only for their taste, but also for their high nutritional value. They have large amounts of high quality protein, essential amino acids, various vitamins and minerals, as well as low fat and calorie contents (Kakon et al., 2012). Rampinelli et al. (2010) found that the fruting bodies of Pleurotus djamor are a source of $\mathrm{P}$ and $\mathrm{K}$, in addition to having low sugar content and not containing fat. They can contribute to the intake of vitamins $B_{1}$ and $B_{2}$.

Furthermore, the Pleurotus genus has attracted great interest from the scientific community for having medicinal properties capable of modulating the immune system, exhibiting hypoglycemic and antithrombotic activities, reducing blood pressure and blood cholesterol, and for having antiinflammatory, anti-microbial, and anti-tumor actions (Chang \& Miles, 2004). Polysaccharides synthesized by Pleurotus, including the $\beta$-glucans, are considered primarily responsible for their therapeutic properties (Zong et al., 2012).

Nevertheless, mushrooms are not part of the traditional diet of the Brazilian population (Bett \& Perondi, 2011), which is evidenced by their low consumption (around 30-60 g per inhabitant) when compared to that of other countries such as France ( $2 \mathrm{~kg} /$ inhabitant), US (1.6 kg/inhabitant), Italy (1.3 kg/inhabitant), and Germany (3.5 kg/inhabitant). About $60 \%$ of the production in Brazil is consumed as fresh mushrooms, and the other $40 \%$ is used by the food processing industry (Kasuya et al., 2005). On the other hand, consumers have been searching for good quality products that offer natural sources of vitamins (Furlani \& Godoy, 2007). The belief that health depends on nutrition has resulted in the need

${ }^{1}$ Programa de Mestrado em Engenharia de Processos, Universidade da Região de Joinville - UNIVILLE, Joinville, SC, Brasil, e-mail: ewisbeck@univille.br

${ }^{2}$ Departamento de Engenharia Química, Universidade da Região de Joinville - UNIVILLE, Joinville, SC, Brasil

${ }^{*}$ Corresponding author 
to adopt healthy eating habits in order to prevent diseases, which should include the entire Brazilian population, based on foods containing the nutrients needed to ensure good health (Sichieri et al., 2000).

Focusing on the prevention and control of nutritional disorders and diseases related to food and nutrition and since wheat is a staple food in the Brazilian diet, the Decree no. 344 (Brasil, 2002) has established that the addition of $4.2 \mathrm{mg}$ iron and $150 \mathrm{mg}$ folic acid per $100 \mathrm{~g}$ wheat flour is mandatory. Bread is an important basic foodstuff worldwide; therefore, it could be an excellent and convenient food item for protein fortification to improve people's nutritional well-being/health. Mushrooms are commonly used as food and can be added to food as a supplement in order to encourage and increase their consumption and provide beneficial health effects through various food products. Bread is consumed all over the world. Various food ingredients have been added to bread formulation to increase its diversity, nutritional value, and product appeal (Ulziijargal et al., 2013; Okafor et al., 2012; Tseng et al., 2010).

The literature on the fortification of wheat flour with mushrooms is scarce. Recently, Ulziijargal et al. (2013) evaluated the supplementation of wheat flour with mycelium. The authors found that when 5\% of lyophilized mycelium of Antrodia camphorata, Agaricus blazei, Hericium erinaceus, and Phellinus linteus are added in the flour, the resulting bread was smaller in volume, lighter in weight, and darker in color. However, the substitution of $5 \%$ wheat flour for mycelium powder did not adversely affect the texture profile of the bread, and it was concluded that overall, the mushroom mycelium could be incorporated into the bread to provide it with beneficial health effects. Okafor et al. (2012) evaluated bread produced by replacing wheat flour with $5,10,15,20$, and $25 \%$ mushroom powder (Pleurotus pulmonarius). It was found that up to $10 \%$ of mushroom powder could be added to wheat flour without causing any adverse effect on the sensory properties of the bread. Tseng et al. (2010) used silver ear mushroom (Tremella fuciformis Berkeley) to substitute wheat flour to make bread. It was found that silver ear mushroom could be incorporated into bread to provide beneficial health effects.

Thus, the objective of this study was to evaluate the production of Pleurotus sajor-caju using peach palm leaves (agro industrial waste) as substrate with different inoculum and rice bran (nitrogen source) fractions. Furthermore, the fruiting bodies obtained under the best cultivation conditions were dried, processed into powder, and used to substitute 5 and $10 \%$ of wheat flour to increase its nutritional value.

\section{Materials and methods}

\subsection{Microorganism and inoculum}

Pleurotus sajor-caju CCB 019 was obtained from the Center for Basidiomycete Cultivation of the University of São Paulo. The strain was grown in wheat dextrose agar (WDA) medium (Furlan et al., 1997) and stored under refrigeration $\left(4^{\circ} \mathrm{C}\right)$. Wheat grains were used as substrate and support to produce the inoculums. The grains were cooked, supplemented with $\mathrm{CaCO}_{3}$ and $\mathrm{CaSO}_{4}$ and sterilized in an autoclave at $121^{\circ} \mathrm{C}$, for $1 \mathrm{~h}$. After the sterilization, they were inoculated with $8 \mathrm{~mm}$ diameter agar discs containing mycelium and incubated at $30^{\circ} \mathrm{C}$ in the dark for 15 days (Bonatti et al., 2004).

\subsection{Fruiting body production}

The experiments conducted for the production of Pleurotus sajor-caju using peach palm leaves are described in Table 1. The inoculum and rice bran fractions were defined according to preliminary results using intermediate values 10 and 5\%, respectively (Experiment 5).

The peach palm leaves were ground into $2-5 \mathrm{~cm}$ particles and packed in raffia bags which were immersed in water for $12 \mathrm{~h}$ and then drained for approximately $2 \mathrm{~h}$ (Madan et al., 1987). Subsequently, $150 \mathrm{~g}$ (dry weight) were packed in transparent polypropylene autoclavable bags $(28 \times 40 \mathrm{~cm})$, supplemented with 2,5 , or $10 \%$ of rice bran (Table 1 ) and closed while maintaining a vent filled with foam in order to allow moderate air exchange and avoid external contamination.

The aim of rice bran supplementation was to supply the necessary nitrogen for the growth of basidiomycete. Lignocellulosic wastes generally have low nitrogen content, $2.76 \%$ in peach palm leaves (Deenik et al., 2000), while rice bran has $4.58 \%$ (Sales-Campos et al., 2010). The plastic bags containing the substrate were homogenized and sterilized at $121^{\circ} \mathrm{C}$, for $2 \mathrm{~h}$.

Inoculation was performed using a laminar air flow cabinet using 5,10 , or $20 \%$ inoculum on dry weight basis (Table 1 ). The incubation conditions used were: $30{ }^{\circ} \mathrm{C}$ in the dark for approximately 20 days, until complete mycelium colonization. Later, the induction of the fruiting bodies formation was achieved using perforated plastic bag (to increase air exchange) and light (270 lux) exposure for a period of $12 \mathrm{~h}$ per day. Temperature was kept around $28{ }^{\circ} \mathrm{C}$ and relative air humidity around 90\% (Bonatti et al., 2004). Harvest point was defined through visual analysis (Sturion \& Oetterer, 1995), when the edges of the pileus appeared flat in the stage prior to sporulation, as shown in Figure 1.

The fruiting bodies were harvested using a scalpel, weighed to determine the wet mass, and dehydrated at $40^{\circ} \mathrm{C}$ for $24 \mathrm{~h}$ with forced air circulation (1370fx, SHEL LAB, Cornelius, USA) to determine the dry mass.

\subsection{Production parameters}

The experiments were performed with 7 replicates and were evaluated in terms of yield ( $\mathrm{Y} \%=$ fresh fruiting bodies mass x 100/dried initial substrate mass), biologic efficiency

Table 1. Experiments for the production of Pleurotus sajor-caju.

\begin{tabular}{ccc}
\hline Experiment & Inoculum fraction (\%) & Rice bran fraction (\%) \\
\hline 01 & 5 & 10 \\
02 & 5 & 2 \\
03 & 20 & 10 \\
04 & 20 & 2 \\
05 (Control) & 10 & 5 \\
\hline
\end{tabular}




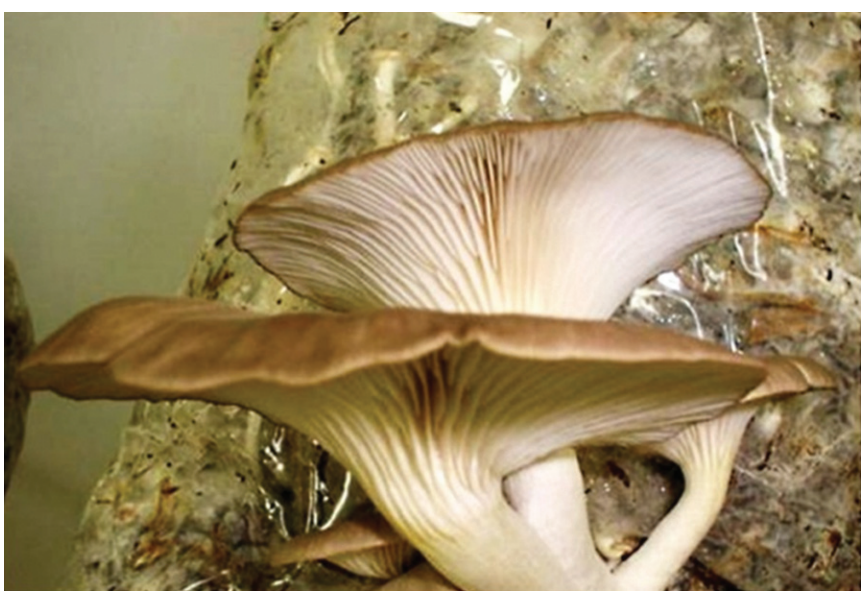

Figure 1. Harvest point of Pleurotus sajor-caju. Source: Primary.

$(\mathrm{BE} \%=$ dried fruiting bodies mass $\mathrm{x} 100 /$ dried initial substrate mass), and productivity $(\mathrm{Pr}-\mathrm{g} / \mathrm{day}=$ dried fruiting bodies mass $/$ total cultivation time) (Holtz et al., 2009).

\subsection{Sample preparation}

Bunge Brasil (Joinville Mill - SC) provided the enriched wheat flour without mixed grains used in the experiments. The dried fruiting bodies were mixed and ground using a blender. These samples were dried to constant mass at $105^{\circ} \mathrm{C}$. The added mushroom powder was used to replace 5 and $10 \%$ w/w of wheat flour (Ulziijargal et al., 2013).

\subsection{Analyses}

The amount of total protein in wheat flour was estimated by the Kjeldahl macro method according to the 46-11A of AACC (American Association of Cereal Chemists, 1999), obtaining the total nitrogen content and later the protein content. The protein content in the mushroom powder was determined in the same way, considering that just $70 \%$ of nitrogen compounds found in mushrooms are digestible by the human body and using 4.38 as correction factor (Bonatti et al., 2004). The fat content was determined gravimetrically after continuous extraction of the samples with sulfuric ether in a Soxhlet apparatus, according to the method of the Instituto Adolfo Lutz (2005). The dietary fiber content was determined by the enzymatic/gravimetric 985.29 method of AOAC (Association of Official Analytical Chemists, 2005). The ash content was calculated based on the sample mass after incineration, according to the physicochemical method of the Instituto Adolfo Lutz (2005). The carbohydrate content was determined by difference, subtracting the sum of protein, fat, fiber, ash, and moisture from $100 \%$, according to the Resolution no. 360, Anvisa (Brasil, 2003). The moisture content was determined by the difference between the weight of wet and dry samples at $105^{\circ} \mathrm{C}$ until reaching constant weight, divided by the wet sample weight, times 100 (Association of Official Analytical Chemists, 2005). For the vitamin $B_{1}$ and $B_{2}$ analyses, an HPLC (Shimadzu) equipped with a C18 column $(15 \mathrm{~cm}$ length and $5 \mu \mathrm{m}$ particle size) and a fluorescence detector was used. The mobile phase used for $\mathrm{B}_{1}$ and $\mathrm{B}_{2}$ consisted of potassium chloride $0.038 \mathrm{~mol} . \mathrm{L}^{-1}$ and methanol. The Instituto Adolfo Lutz (2005) method was used for the measurements of phosphorus, potassium, and iron by atomic absorption spectrometry with flame. The sodium content was determined according to the method of ANFAL (Associação Nacional dos Fabricantes de Alimentos, 2005). The moisture (\%), wet gluten (\%), color ( $\left.\mathrm{L}^{\star}\right)$, and Falling Number (seconds) analyses were performed with the wheat flour without and with 5 or $10 \%$ mushroom powder (item 2.4). The wet gluten (\%) determination was performed according to the AACC method 38-12 (American Association of Cereal Chemists, 1999) by washing the sample ( $10 \mathrm{~g})$ with a $2 \%$ sodium chloride solution, followed by separation of gluten forming insoluble proteins (gliadins and glutenins) using the Glutomatic apparatus (Peter Instruments North America Inc., Reno, USA). The wet gluten percentage was obtained on $14 \%$ moisture basis by calculating the ratio of the total weight of wet gluten/g to $100 \%$ sample moisture. Luminosity $\left(\mathrm{L}^{*}\right)$ was determined using a Minolta colorimeter, according to the AACC method 14-22 (American Association of Cereal Chemists, 1999). The Falling Number was obtained by measuring the ability of the alphaamylase enzyme to liquefy a starch gel (in seconds), according to the AACC method 56-81B (American Association of Cereal Chemists, 1999).

\subsection{Statistical analysis}

All data obtained were submitted to the outlier rejection test (Dixon Q test) (Rorabacher, 1991). The results of the centesimal composition of the fruiting bodies and the wheat flour were expressed as means, and the results of the physicochemical analyses were submitted to analysis of variance using the Tukey Test with significance level of $5 \%$ (Anova).

\section{Results and discussion}

\subsection{Evaluation of fruiting body production}

Results of the Y (\%), BE (\%), and Pr (g/day) values are presented in Table 2.

Table 2 shows that there is no statistical difference in the $\mathrm{Y}$ of experiment 5 (control) in relation to the other experiments. The Biologic Efficiency (EB) of experiment 3 was higher $(4.5 \pm 0.3 \%)$ than that of the control experiment $(3.3 \pm 0.6 \%)$. The same was observed for $\mathrm{Pr}$, which was higher in experiment 3 $(0.36 \pm 0.04 \mathrm{~g} /$ day $)$ and lower in experiment $4(0.21 \pm 0.03 \mathrm{~g} /$ day $)$ compared to that of the control $(0.30 \mathrm{~g} /$ day $)$.

When compared to the yield (Y), the biological efficiency $(\mathrm{BE})$ is a more accurate parameter since it deals with the relationship between the dry fruiting body weight and the dry substrate weight, that is, without moisture interference. Thus, the best results for Pleurotus sajor-caju production in peach palm leaves in terms of Biological Efficiency (BE) and Productivity (Pr) were obtained using 20\% (w/w) inoculum and 10\% (w/w) rice bran (Experiment 3).

Castro et al. (2007) obtained 55.76\% yield with P. sajor-caju cultivated in cotton textile waste with $10 \%$ wheat flour, and Patil (2012) obtained yield values of $84.56 \%$ in soybean straw. 
Pleurotus sajor-caju had $48.4 \%$ yield (Experiment 3 - Table 2), similar to the results found for P. ostreatus (46.67\%) banana straw (Furlan et al., 2008), and P. pulmonarius (43\%) in corn straw (Oliveira et al., 2007). Biological efficiency values varying from 4.08 to $5.03 \%$ were found in literature (Bhatti et al., 2007; Holtz et al., 2009; Furlan et al., 2008), values that are similar to those found in this study (4.5\%). Holtz et al. (2009) found productivity value of $0.37 \mathrm{~g} /$ day with $P$. ostreatus cultivated in cotton textile waste; this value is very close to that found in this study, $0.36 \mathrm{~g} /$ day.

\subsection{Evaluation of nutritional potential}

The production of edible dried and ground mushrooms from the drying and grinding of fruiting bodies can be an option for the nutritional enrichment of diets. One of the objectives of this study was to add wheat flour with 5 and $10 \%$ mushroom powder and evaluate its nutritional value and characteristics before and after the addition. Therefore, Table 3 shows the contents of carbohydrates, total fat, fibers, proteins, phosphorus, potassium, iron, sodium and vitamin in the mushroom powder of the fruiting bodies, the wheat flour, and the wheat flour with 5 and $10 \%$ mushroom powder (w/w), which were compared to the values as established in the Decree no. 27 of $13^{\text {th }}$ January 1998 of Anvisa - National Agency of Sanitary Surveillance (Brasil, 1998), which approves the Technical Regulation in relation to Complementary Nutritional Information (statements related to nutrient contents).

According to Table 3, the mushroom powder can be considered a food containing sugars, but with low fat content, very low sodium content, high fiber content, proteins, phosphorus, potassium, iron, riboflavin, and source of thiamine. The wheat flour used in this study contained sugars, had low fat content, and high protein, iron, and thiamine content; it was a source of phosphorus and contained fibers, potassium, and sodium.

In general, the addition of with 5 or $10 \%$ mushroom powder did not change the classification of the flour when compared to the values according to Decree no. 27 of Anvisa (Brasil, 1998), except for the phosphorus content, which went from being a phosphorus source in the wheat flour to being excessive phosphorus content in the wheat flour with 5 or $10 \%$ mushroom powder.

However, the addition of wheat flour with 5 or $10 \%$ mushroom powder reduced the sugar content, but it did not increase the fat content, remaining similar to the flour without

Table 2. Mean values \pm standard deviation obtained to study the effect of inoculum and rice bran fractions on Y (Yield), BE (Biologic Efficiency) and $\operatorname{Pr}$ (Productivity).

\begin{tabular}{|c|c|c|c|c|c|}
\hline \multirow{2}{*}{ Experiment } & \multirow[b]{2}{*}{$\begin{array}{l}\text { Inoculum Fraction } \\
\qquad(\%)\end{array}$} & \multirow[b]{2}{*}{$\begin{array}{c}\text { Rice bran fraction } \\
(\%)\end{array}$} & \multicolumn{3}{|c|}{ Mean \pm standard deviation } \\
\hline & & & $\begin{array}{c}\mathrm{Y} \\
(\%)\end{array}$ & $\begin{array}{l}\mathrm{BE} \\
(\%)\end{array}$ & $\begin{array}{c}\operatorname{Pr} \\
\text { (g/day) }\end{array}$ \\
\hline 1 & 5 & 10 & $31.4 \pm 3.9 a$ & $2.9 \pm 0.4 b$ & $0.21 \pm 0.05 d$ \\
\hline 2 & 5 & 2 & $45.8 \pm 7.7 a$ & $3.4 \pm 0.3 b$ & $0.27 \pm 0.03 d$ \\
\hline 3 & 20 & 10 & $48.4 \pm 16.1 a$ & $4.5 \pm 0.3 c$ & $0.36 \pm 0.04 e$ \\
\hline 4 & 20 & 2 & $34.4 \pm 5.1 a$ & $3.2 \pm 0.4 b$ & $0.21 \pm 0.03 f$ \\
\hline
\end{tabular}

Different lowercase letters in the same column indicate that the means differed statistically according to the Tukey's test $(\mathrm{P}<0.05)$ between experiment 5 (control) and the other experiments.

Table 3. Mean carbohydrate (sugars), total fat, proteins, fibers, phosphorus, potassium, iron, sodium, and vitamin values for the mushroom powder, wheat flour, and wheat flour with 5 and 10\% mushroom powder and comparison with Decree no. 27 (Brasil, 1998) values.

\begin{tabular}{|c|c|c|c|c|}
\hline Nutrients & $\begin{array}{l}\text { P. sajor-caju/ } \\
\text { According to } \\
\text { Decree no. } 27^{\star}\end{array}$ & $\begin{array}{l}\text { Wheat flour/ } \\
\text { According to } \\
\text { Decree no. } 27^{\star}\end{array}$ & $\begin{array}{l}\text { Wheat flour with } 5 \% \\
\text { mushroom powder/ } \\
\text { According to } \\
\text { Decree no. } 27^{*}\end{array}$ & $\begin{array}{l}\text { Wheat flour with } 10 \% \\
\text { mushroom powder / } \\
\text { According to } \\
\text { Decree no. } 27^{\star}\end{array}$ \\
\hline Sugars $(g / 100 g)$ & 29.9 / Contain & 72.3 / Contain & 70.2 / Contain & 68.1 / Contain \\
\hline Fat $(\mathrm{g} / 100 \mathrm{~g})$ & 1.2 / Low content & 1.6 / Low content & 1.6 / Low content & $1.6 /$ Low content \\
\hline Fibers $(\mathrm{g} / 100 \mathrm{~g})$ & 15.9 / High content & $<0.50 /$ Not containing & $0.79^{\prime}$ Not containing ${ }^{\star *}$ & 1.6/ Not containing ${ }^{\star *}$ \\
\hline Proteins $(\mathrm{g} / 100)$ & 42.9 / High content & 12.4 / High content & 13.9 / High content & 15.5 / High content \\
\hline Phosphorus (mg/100g) & 1602.8 / High content & 184.7 / Source & 255.6 / High content & 326.4 / High content \\
\hline Potassium (mg/100g) & 2722.6 / High content & 437.5 / Not containing & 551.8 / Not containing & 666.1 / Not containing \\
\hline Iron $(\mathrm{mg} / 100 \mathrm{~g})$ & 8.7 / High content & 4.2 / High content & 4.4 / High content & 4.6 / High content \\
\hline Sodium (mg/100g) & 23.8 / Very low content & 2.1/ Not containing & 3.2 / Not containing & 4.2 / Not containing \\
\hline Thiamine $(\mathrm{mg} / 100 \mathrm{~g})$ & 0.34 / Source & 0.67 / High content & 0.65 / High content & 0.64 / High content \\
\hline Riboflavin (mg/100g) & 0.57 / High content & $<0.40 /$ Not containing ${ }^{* *}$ & $0.028 /$ Not containing & 0.057 / Not containing ${ }^{\star *}$ \\
\hline \multicolumn{5}{|c|}{ 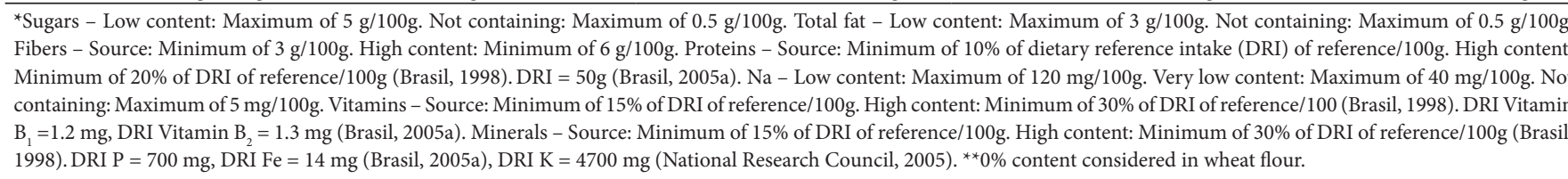 } \\
\hline
\end{tabular}


the addition of mushroom powder. The contents of fiber, proteins, phosphorus, potassium, iron, and riboflavin were increased, mainly when $10 \%$ mushroom powder was added to the wheat flour. Regarding the sodium content, the contents in the wheat flour with 5 or $10 \%$ mushroom powder increased; however, they maintained the same classification according to the Decree no. 27 of Anvisa (Brasil, 1998), in other words, "products not containing $\mathrm{Na}$.

Okafor et al. (2012) observed that the supplementation of wheat flour with $10 \%$ mushroom powder (Pleurotus pulmonarius) increased the crude protein content significantly, from 9.7 to $13.14 \%$, crude fiber from 0.3 to $1.06 \%$, and ash from 0.76 to $1.44 \%$. They verified that the carbohydrate content in the wheat flour $(75.94 \%)$ decreased in the wheat flour with $10 \%$ mushroom powder (71.07\%). These results are similar to those of the present study (Table 3).

\subsection{Physicochemical evaluation}

Table 4 presents the results of moisture (\%), wet gluten (\%), color $\left(\mathrm{L}^{*}\right)$, and Falling Number (FN) analyses conducted with the flour with and without 5 and $10 \%$ mushroom powder.

One of the great concerns regarding flours is moisture control, which can have a direct influence on the quality of food during manufacture (Brasil, 2005b; Empresa Brasileira de Pesquisa Agropecuária, 2009). The Resolution RDC no. 263 of $22^{\text {nd }}$ September 2005 (Brasil, 2005c) establishes that the moisture content of flours should have a maximum value of $15.0 \%$. The results obtained for the flour without and with 5 or $10 \%$ mushroom powder (Table 4) show a maximum value of $14.0 \%$, in other words, they meet legal specifications.

The gluten forming proteins are basically responsible for the functional properties of the wheat flour and are related to the strength of the flour (it represents the work deformation of the dough and indicates the bread-making quality of the flour) (Empresa Brasileira de Pesquisa Agropecuária, 2009). In Table 4, it can be observed that the gluten content in the wheat flour and the wheat flour with 5 and $10 \%$ mushroom powder showed no statistically significant difference with a $29.8 \%$ average of wet gluten. The results, therefore, show that wheat flour with mushroom powder maintained its bread-making quality. Table 4 also shows that the gluten content in the wheat flour and the wheat flour with 5 and $10 \%$ mushroom powder showed no statistically significant difference with a $29.8 \%$ average of wet gluten. Therefore, the results show that wheat flour with mushroom powder maintained its bread-making quality.
Mohammed et al. (2009) evaluated wheat flour and wheat breads supplemented with teff and concluded that breads supplemented with teff flour, up to a $5 \%$ level, are organoleptically and nutritionally acceptable. The authors found $28.6 \%$ wet gluten in wheat flour; however, when $5 \%$ teff flour was added, this value decreased significantly to $21.6 \%$.

According to Kajishima et al. (2003), flour coloring is a prime factor for its acceptance or rejection. According to Decree no. 354 of July 1996 of Anvisa (Brasil, 1996), flour coloring must be white with light yellow, brown, or even gray tones. Furthermore, according to Embrapa Trigo (Empresa Brasileira de Pesquisa Agropecuária, 2009), although consumers prefer the whitest flours, they do not always offer the best quality for all final products. The luminosity measurement $\left(\mathrm{L}^{*}\right)$ has a scale from zero (black) to 100 (white), that is, the closer to 100 , the whiter the flour. In Table 4, it can be observed that the flour without the addition of mushroom powder showed a luminosity value of $92.3\left(L^{*}\right)$. However, the flour enriched with mushroom powder was darker, equivalent to $89.2\left(\mathrm{~L}^{*}\right)$ and $88.1\left(\mathrm{~L}^{\star}\right)$ for flour with 5 and $10 \%$ mushroom powder, respectively. This color was expected, due to the dark color of the mushroom powder and its ash content $(7.4 \mathrm{~g} / 100 \mathrm{~g})$. Nonetheless, these results did not affect the product quality since it was nutritionally enriched (Table 3). Today, consumers search for products that can offer health benefits, especially for natural additives, ingredients, and foods (Gandra et al., 2008).

In a study conducted by Ulziijargal et al. (2013), in which $5 \mathrm{~g}$ of mycelium powder of Antrodia camphorata, Agaricus blazei, Hericium erinaceus, and Phellinus linteus were added to $95 \mathrm{~g}$ wheat flour (5\%) and other ingredients for bread preparation, it was observed that the bread without the addition of mycelium had $70.68\left(L^{*}\right)$, and in the breads in which mycelium was added, the luminosity dropped to $62.45\left(\mathrm{~L}^{*}\right)$ with Antrodia camphorata, $54.84\left(\mathrm{~L}^{*}\right)$ with Agaricus blazei, $47.47\left(\mathrm{~L}^{*}\right)$ with Hericium erinaceus, and $66.64\left(\mathrm{~L}^{*}\right)$ with Phellinus linteus. The authors concluded that all breads supplemented with mycelium were slightly colored (brownish). The change in color in the bread supplemented with mycelium could be related to the original pigments of the mycelium and with the oxidation of the phenolic compounds of the mycelia during baking. However, the authors suggest that the brownish color could be attractive to the consumer. On the other hand, Tseng et al. (2010) evaluated bread with silver ear flour and found that the white bread showed $76.75\left(\mathrm{~L}^{*}\right)$, while the addition of $5 \%$ silver ear flour resulted in bread with less color $82.27\left(\mathrm{~L}^{\star}\right)$.

Table 4. Mean \pm standard deviation results obtained for wheat flour without and with 5 and $10 \%$ mushroom powder.

\begin{tabular}{lcccc}
\hline & $\begin{array}{c}\text { Moisture } \\
(\%)\end{array}$ & $\begin{array}{c}\text { Wet gluten } \\
(\%)\end{array}$ & $\begin{array}{c}\text { Color } \\
\left(\mathrm{L}^{*}\right)\end{array}$ & $\begin{array}{c}\text { FN } \\
(\mathrm{s})\end{array}$ \\
\hline $\begin{array}{l}\text { Wheat flour } \\
\begin{array}{l}\text { Wheat flour with 5\% } \\
\text { mushroom powder }\end{array}\end{array}$ & $13.1 \pm 0.14 a$ & $29.4 \pm 0.16 a$ & $92.3 \pm 0.05 a$ & $483.5 \pm 4.95 a$ \\
$\begin{array}{l}\text { Wheat flour with 10\% } \\
\text { mushroom powder }\end{array}$ & $14.0 \pm 0.28 b$ & $29.8 \pm 0.08 a$ & $89.2 \pm 0.28 b$ & $457.5 \pm 6.36 b$ \\
\end{tabular}

Different lowercase letters in the same column indicate that the means differed statistically according to the Tukey's test $(\mathrm{P}<0.05)$. 
The Falling Number (FN) results obtained in the flour sample without the addition of mushroom powder was $483.5 \mathrm{~s}$, and in the flour with 5 and $10 \%$ mushroom powder this number dropped to 457.5 and $431.5 \mathrm{~s}$, respectively. Such decrease could be due to the fact that the mushroom powder showed a larger particle size than that of the flour, hindering the formation of hydrolyzed gel. However, the results are higher than those expected for bread-making.

According to Costa et al. (2008), flours with high FN values (minimum $250 \mathrm{~s}$ ) are compatible with the wheat enhancer, which is preferred in mixture industries in different proportions with flours of low FN value for the purpose of improving the end quality of the product. On the other hand, FN values lower than $250 \mathrm{~s}$ are compatible with soft wheat flours, and these flours are more appropriate for bread-making. Low FN values can be related to high $\alpha$-amylase activity so that the flours with high contents of this enzyme tend to produce low amounts of sticky products. These authors evaluated different domestic and imported wheat flours and verified FN values ranging between 64 and 223 (s) for domestic flours and between 293 and 430 (s) for imported flours. Mohammed et al. (2009) observed that the substitution of wheat flour for teff flour caused a significant increase in $\mathrm{FN}$, indicating less amylase activity. In the present study, (Table 4) the FN decreased when the mushroom powder increased. This could be due to the fact that the Pleurotus genus has the ability to produce amylases (Souza et al., 2008).

In general, it was confirmed that wheat flour with 5 or $10 \%$ mushroom powder did not drastically change the physicochemical characteristics, such as moisture, wet gluten, color, and falling number, evaluated in wheat flour.

\section{Conclusions}

The best results in terms of Yield (48.4 $\pm 16.1 \%)$, Biological Efficiency $(4.5 \pm 0.3 \%)$, and Productivity $(0.36 \pm 0.04$ g/day $)$ were obtained using $20 \%$ inoculum fraction and $10 \%$ rice brand fraction.

The fruiting bodies of Pleurotus sajor-caju CCB 019 cultivated in peach palm leaves with $10 \%$ rice bran and $20 \%$ inoculum had $29.91 \mathrm{~g} / 100 \mathrm{~g}$ total carbohydrates, $42.92 \mathrm{~g} / 100 \mathrm{~g}$ proteins, $1.24 \mathrm{~g} / 100 \mathrm{~g}$ fat, $15.93 \mathrm{~g} / 100 \mathrm{~g}$ fibers, $7.42 \mathrm{~g} / 100 \mathrm{~g}$ ash, $1602.78 \mathrm{mg} / 100 \mathrm{~g}$ phosphorus, $2722.58 \mathrm{mg} / 100 \mathrm{~g}$ potassium, $8.73 \mathrm{mg} / 100 \mathrm{~g}$ iron, $23.75 \mathrm{mg} / 100 \mathrm{~g}$ sodium, $0.34 \mathrm{~g} / 100 \mathrm{~g}$ thiamine, and $0.57 \mathrm{mg} / 100 \mathrm{~g}$ riboflavin. Pleurotus sajor-caju mushroom powder can be considered a food containing sugars, but with low fat content, very low sodium content, high fiber, protein, phosphorus, potassium, iron, and riboflavin content, and a source of thiamine.

The wheat flour with 5 or $10 \%$ mushroom powder reduced the sugar content, but it did not increase the fat content, remaining similar to the flour without the addition of mushroom powder. The fiber, protein, phosphorus, potassium, iron, and riboflavin contents were increased mainly when $10 \%$ mushroom powder was added to the wheat flour. With regard to the sodium content, the contents in the wheat flour with 5 or $10 \%$ mushroom powder increased, however, they maintained the same classification according to Decree no. 27 of Anvisa (Brasil, 1998), that is, "products not containing Na".

The finding that the wheat flour with 5 or $10 \%$ mushroom powder did not drastically change the physicochemical characteristics such as moisture, wet gluten, color, and falling number, together with the fact that the mushroom powder increased the nutritional value of the wheat flour, suggests that wheat flour with $10 \%$ mushroom powder provides nutritional enrichment without changing the characteristics evaluated. Furthermore, due to the fact that mushrooms are not part of the traditional diet of the Brazilian population, currently showing a consumption of just $30 \mathrm{~g}$ per inhabitant, the addition of wheat flour with mushroom powder may contribute to increase the consumption of mushrooms in the country, thus providing a positive impact on the health of the population.

\section{Acknowledgements}

The authors are grateful for the financial support provided by the National Council for Scientific and Technological Development (CNPq) and Research and Support Fund (FAP) from UNIVILLE and to Bunge Brazil (Mill Joinville - SC) for providing the wheat flour used in the experiments.

\section{References}

American Association of Cereal Chemists - AACC. (1999). Approved methods of the AACC. St. Paul: AACC. Retrieved from http:// methods.aaccnet.org/toc.aspx

Associação Nacional dos Fabricantes de Alimentos - ANFAL. (2005). Compêndio brasileiro de alimentação animal (Método 48). Campinas: CBNA/SDR/MA.

Association of Official Analytical Chemists - AOAC. (2005). Official Methods of the AOAC International. Maryland: AOAC.

Bett, C. F., \& Perondi, M. A. (2011). Análise do mercado de cogumelos comestíveis e medicinais: uma prospecção de alternativa de renda para a agricultura familiar na região Sudoeste do Paraná. Synergismus scyentifica UTFPR, 6(1), 1-9.

Bhatti, M. I., Jiskani, M. M., Wagan, K. H., Pathan, M. A., \& Magsi, M. R. (2007). Growth development and yield of oyster mushroom Pleurotus ostreatus (JACQ.EX.FR) Kummer as affected by different spawn rates. Pakistan Journal of Botany, 39(7), 2685-2692.

Bonatti, M., Karnopp, P., Soares, H. M., \& Furlan, S. A. (2004). Evaluation of Pleurotus ostreatus and Pleurotus sajor-caju nutritional characteridtics when cultivated in different lignocellulosic wastes. Food Chemistry, 88(3), 425-428. http://dx.doi.org/10.1016/j. foodchem.2004.01.050

Bovi, M. L. A. (2000). O agronegócio palmito de pupunha. $O$ Agronômico, 52(1), 10-12.

Brasil, Ministério da Saúde, Agência Nacional de Vigilância Sanitária. (1996). Norma técnica referente a farinha de trigo (Portaria no 354 de 18 de julho de 1996). Diário Oficial da República Federativa do Brasil.

Brasil, Ministério da Saúde, Agência Nacional de Vigilância Sanitária. (1998). Regulamento técnico referente à informação nutricional complementar (declarações relacionadas ao conteúdo de nutrientes) (Portaria nº 27 de 13 de janeiro de 1998). Diário Oficial da República Federativa do Brasil. 
Brasil, Ministério da Saúde, Agência Nacional de Vigilância Sanitária. (2002). Regulamento técnico para a fortificação e das farinhas de milho com ferro e ácido fólico (Resolução RDC no 344 de 13 de dezembro de 2002). Diário Oficial da União. Retrieved from http:// www.anvisa.gov.br

Brasil, Ministério da Saúde, Agência Nacional de Vigilância Sanitária. (2003). Regulamento técnico sobre rotulagem nutricional de alimentos embalados (Resolução RDC no 360 de 23 de dezembro de 2003). Diário Oficial da União. Retrieved from http://www.anvisa.gov.br

Brasil, Ministério da Saúde, Agência Nacional de Vigilância Sanitária. (2005a). Regulamento técnico sobre a ingestão diária recomendada (IDR) de proteína, vitaminas e minerais (Resolução RDC n 269, de 22 de setembro de 2005). Diário Oficial da República Federativa do Brasil.

Brasil, Ministério da Agricultura e do Abastecimento. (2005b). Regulamento técnico de identidade e qualidade da farinha de trigo (Instrução Normativa no 8 de 02 de junho de 2005). Diário Oficial da República Federativa do Brasil.

Brasil, Ministério da Saúde, Agência Nacional de Vigilância Sanitária. (2005c). Regulamento técnico para produtos de cereais, amidos, farinha e farelos (Resolução RDC n 263 de 22 de setembro de 2005). Diário Oficial da União. Retrieved from http://www.anvisa.gov.br

Carvalho, C. S. M., Sales-Campos, C., \& Andrade, M. C. N. (2010). Mushrooms of the Pleurotus genus: a review of cultivation techniques. Interciencia, 35(3), 177-182.

Castro, A. L. A., Paiva, P. C. A., Banys V. L., Dias, E. S., \& Santos, J. (2007). Avaliação da produção de Pleurotus sajor caju (Fr.)Singer utilizando resíduo do beneficiamento têxtil do algodão como substrato. Ciência e Agrotecnologia, 31(5), 1286-1290. http://dx.doi. org/10.1590/S1413-70542007000500002

Chang, S. T., \& Miles, P. G. (2004). Mushrooms: cultivation, nutritional value, medicinal effect, and environmental impact. New York: CRC Press. http://dx.doi.org/10.1201/9780203492086

Costa, M. G., Souza, E. L., Stantford, T. L. M., \& Andrade, S. A. C. (2008). Qualidade tecnológica de grãos e farinhas de trigo nacionais e importados. Food Science and Technology, 28(1), 220-225.

Deenik J., Ares, A., \& Yost, R.S. (2000). Fertilization response and nutrient diagnosis in peach palm (Bactris gasipaes): a review. Nutrient Cyclingin Agroecosystems, 56(3), 195-207. http://dx.doi. org/10.1023/A:1009847508353

Empresa Brasileira de Pesquisa Agropecuária - Embrapa. (2009). Descrição dos métodos usados para avaliar a qualidade de trigo (Documentos online 112). Brasília: Embrapa Trigo. Retrieved from http://www.cnpt.embrapa.br/biblio/do/p_do112_5.htm

Furlan, S. A., Gern, R. M. M., Wisbeck, E., Bonatti, M., Silveira, M. L. L., \& Silva, H. H. (2008). Possibilities of Pleurotus aplications in food health and environmental technologies. In A. Koutinas, A. Pandey \& C. Larroche (Eds.), Current topics on bioprocess in food industry (Vol. 2, cap. 16, pp. 197-203). New Delhi: Asiatech Publishers.

Furlan, S. A., Virmond, L. J., Miers, D. A., Bonatti, M., Gern, R. M. M., \& Jonas, R. (1997). Mushrooms strains able to grow at high temperatures and low $\mathrm{pH}$ values. World Journal Microbiology and Biotechnology, 13(6), 689-692. http://dx.doi. org/10.1023/A:1018579123385

Furlani, R. P. Z., \& Godoy, H. T. (2007). Valor nutricional de cogumelos comestíveis. Food Science and Technology, 27(1), 54-157.

Gandra, K. M., Del Bianchi, M., Godoy, V. P., Queiroz, F. P. C., \& Steel, C. J. (2008). Aplicação de lipase e monoglicerídeos em pão de forma enriquecido com fibras. Food Science and Technology, 28(1), 182-192.
Holtz, M., Borges, G. M., Furlan, S. A., \& Wisbeck, E. (2009). Cultivo de Pleurotus ostreatus utilizando resíduos de algodão da indústria têxtil. Revista de Ciências Ambientais, 3(1), 37-51.

Instituto Adolfo Lutz - IAL. (2005). Métodos físico-químicos para análise de alimentos. São Paulo: IAL.

Kajishima, S., Pumar, M., \& Germani, R. (2003). Efeito de adição de diferentes sais de cálcio nas características da massa e na elaboração de pães francês. Food Science and Technology, 23(2), 222-225.

Kakon, A. J., Choudhury, M. B. K., \& Saha, S. (2012). Mushroom is an ideal food supplement. Journal of Dhaka National Medical College \& Hospital, 18(1), 58-62. http://dx.doi.org/10.3329/jdnmch. v18i1.12243

Kasuya, M. C., Vanetti, M. C., Manabe, A., Santana, C. C., \& Mendonça, M. (2005). Shiitake log cultivation in Brazil. In MushWorld, Shiitake cultivation (Mushroom Growers' Handbook 2, pp. 61-66). Korea: MushWorld.

Kong, W. S. (2004). Descriptions of commercially important Pleurotus species. In MushWorld, Oyster mushroom cultivation (Mushroom Growers' Handbook 1, pp. 54-61). Korea: MushWorld.

Madan, M., Vasudevan, P., \& Sharma, S. (1987). Cultivation of Pleurotus sajor-caju on different agro-wastes. Biological Wastes, 22(4), 241-250. http://dx.doi.org/10.1016/0269-7483(87)90110-8

Medina, J. C. (1990). Banana: cultura, matéria-prima, processamento e aspectos econômicos. Campinas: ITAL.

Mohammed, M. I. O., Mustafa, A. I., \& Osman, G. A. M. (2009). Evaluation of wheat breads supplemented with Teff (Eragrostis tef (ZUCC.) Trotter) Grain flour. Australian Journal of Crop Science, 3(4), 207-212.

National Research Council - NRC. (2005). Dietary Reference Intakes for water, potassium, sodium, chloride, and sulfate. Washington: The National Academies Press. Retrieved from http://www.nap.edu/ openbook.php?record_id=10925\&page $=186$

Okafor, J. N. C., Okafor, G. I., Ozumba, A. U. \& Elemo, G. N. (2012). Quality characteristics of bread made from wheat and Nigerian oyster mushroom (Pleurotus pulmonarius) powder. Pakistan Journal of Nutrition, 11(1), 5-10. http://dx.doi.org/10.3923/pjn.2012.5.10

Oliveira, M. A., Donega, M. A., Peralta, R. M., \& Souza, C. G. M. (2007). Produção de inóculo de cogumelo comestível Pleurotus pulmonarius (Fr.) Quélet - CCB 19 a partir de resíduos da agoindústria. Food Science and Technology, 27(Supl.), 84-87.

Patil, S. S. (2012). Cultivation of Pleurotus sajor-caju on different agro wastes. Science Research Reporter, 2(3), 225-228.

Philippoussis, A. N. (2009). Production of mushrooms using agroindustrial residues as substrates. In P. S. Nigam \& A. Pandey (Eds.), Biotechnology for agro-industrial residues utilization (pp.163-196). New York: Springer. http://dx.doi.org/10.1007/978-1-4020-99427_9

Rampinelli, J. R., Silveira, M. L. L., Gern, R. M. M., Furlan, A. S., Ninow, J. L., \& Wisbeck, E. (2010). Valor nutricional de Pleurotus djamor cultivado em palha de bananeira. Alimentos e Nutrição, 21(2), 197-202.

Rorabacher, D. B. (1991). Statistical treatment for rejection of deviant values: critical values of Dixon's “Q” parameter and related sub range rations at the $95 \%$ confidence level. Analitycal Chemistry, 63(2), 139-146. http://dx.doi.org/10.1021/ac00002a010

Sales-Campos, C., Oliveira, L. A., Araujo, L. M., Minhoni, M. T. A., \& Andrade, M. C. N. (2010). Análise físico-química e composição nutricional da matéria prima e de substratos pré e pós cultivo de Pleurotus ostreatus. Interciencia, 35(1), 70-76. 
Sichieri, R., Coitinho, D. C., Monteiro, J. B., \& Coutinho, W. F. (2000). Recomendações de alimentação e nutrição saudável para a população Brasileira. Arquivos Brasileiros de Endocrinologia \& Metabologia, 44(3), 227-232. http://dx.doi.org/10.1590/S000427302000000300007

Soto, G., Luna-Orea, P., Wagger, M. G., Smyth, T. J., \& Alvarado, A. (2005). Foliage residue decomposition and nutrient release in peach palm (Bactris gasipaes Kunth) plantations for heart-of-palm production in Costa Rica. Agronomy Journal, 97(5), 1396-1402. http://dx.doi.org/10.2134/agronj2004.0250

Souza, H. Q., Oliveira, L. A., \& Andrade, J. S. (2008). Seleção de Basidiomycetes da Amazônia para produção de enzimas de interesse biotecnológico. Food Science and Technology, 28(Supl.), 116-124.
Sturion, G. L., \& Oetterer, M. (1995). Composição química de cogumelos comestíveis (Pleurotus spp.) originados de cultivos em diferentes substratos. Food Science and Technology, 15(2), 189-193.

Tseng, Y. H., Yang, J. H., Li, R. C., \& Mau, J. L. (2010). Quality of bread supplemented with silver ear. Journal of Food Quality, 33(1), 59-71. http://dx.doi.org/10.1111/j.1745-4557.2009.00288.x

Ulziijargal, E., Yang, J. H., Lin, L. Y., Chen, C. P., \& Mau, J. L. (2013). Quality of bread supplemented with mushroom mycelia. Food Chemistry, 138(1), 70-76. PMid:23265457. http://dx.doi. org/10.1016/j.foodchem.2012.10.051

Zong, A., Cao, H., \& Wang, F. (2012). Anticancer polysaccharides from natural resources: a review of recent research. Carbohydrate Polymers, 90(4), 1395-1410. PMid:22944395. http://dx.doi. org/10.1016/j.carbpol.2012.07.026 